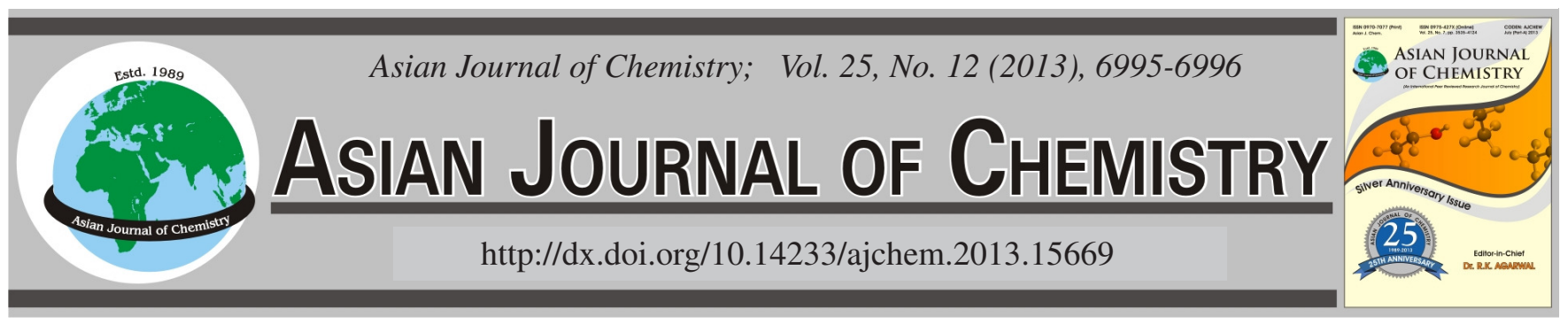

NOTE

\title{
Synthesis and Characterization of Various Xanthates and Their Effects on Germination and Early Seedling Growth in Wheat (Triticum aestivum L.)
}

\author{
AlKa Rani* and C.S. GuPta
}

Department of Chemistry, Hindu College, Moradabad-244 001, India

*Corresponding author: E-mail: satishpps@yahoo.co.in

(Received: 1 March 2013;

Accepted: 10 June 2013)

AJC-13622

\begin{abstract}
Potassium $n$-propyl xanthate potassium iso-propyl xanthate, potassium $n$-butyl xanthate and potassium iso-butyl xanthate were synthesized and characterized by melting point, elemental analysis and infrared spectra and their effect on germination and early seedling growth in wheat (Triticum aestivum L.) were studied. All chemical treatments decreased per cent germination length and dry weight of shoots decreased at all concentrations except at 5 and $10 \mathrm{ppm} n$-propyl xanthate. Root length also decreased except at 5,10 and $25 \mathrm{ppm}$ of potassium iso-propyl xanthate and potassium iso-butyl xanthate, root dry weight decreased with all chemical treatments except at 5 and $10 \mathrm{ppm}$ in case of potassium $n$-butyl xanthate.
\end{abstract}

Key Words: Xanthate, Wheat.

Reactions of plants to exogenously applied chemicals offer a wide range of possibilities for exploring physiological phenomena. The facilities with which chemicals can modify plant growth and development indicate a relatively easy entry of applied chemicals into the cells of organism. It is now a recognized fact that most, if not all, physiological activities of the plant are regulated by a variety of chemicals such as auxins, gibberellins, kinins and inhibitors including phenols. These growth promotors and inhibitors have been shown to influence dormancy, germination, morphogenesis, growth, flowering, fruit set and yield ${ }^{1-14}$. This study reports the synthesis and characterization of various xanthates and their effect on germination and early seedling growth in wheat (Triticum aestivum $\mathrm{L}$.).

Xanthates were prepared by dissolving potassium hydroxide in distilled water, adding benzene followed by respective alcohol ( $n$-propanol, iso-propanol, $n$-butanol, iso-butanol with constant stirring and finally adding carbon disulphide very slowly and maintaining the temp. $4-5^{\circ} \mathrm{C}$ (benzene is toxic so, appropriate precaution is necessary). The molar ratio of $\mathrm{KOH}$, alcohal and $\mathrm{CS}_{2}$ was 1:1:1. The solid product was filtered and washed with ether dried under vaccum and used for germination studies. The physico-chemical properties of purified various xanthates are shown in Table- 1 .

The seeds of wheat Pusa Ruby Lot No.- 7-10Cy (d)-19 were obtained from the National seed Corporation Ltd., New

\begin{tabular}{lccc}
\hline \multicolumn{5}{c}{ TABLE-1 } \\
\multicolumn{4}{|c}{$\begin{array}{c}\text { SOME PHYSICOCHEMICAL PROPERTIES OF } \\
\text { SYNTHESIZED VARIOUS XANTHATE }\end{array}$} \\
\hline \multicolumn{1}{|c}{ Compound } & $\begin{array}{c}\text { Colour and } \\
\text { m.p. }\end{array}$ & $\begin{array}{c}\mathrm{C}=\mathrm{S} \\
\left(\mathrm{cm}^{-1}\right)\end{array}$ & $\begin{array}{c}\mathrm{C}-\mathrm{O}-\mathrm{C} \\
\left(\mathrm{cm}^{-1}\right)\end{array}$ \\
\hline $\left.\begin{array}{l}\text { Potassium } n \text {-propyl } \\
\text { xanthate }\left(\mathrm{C}_{4} \mathrm{H}_{7} \mathrm{OKS}\right.\end{array}\right)$ & $\begin{array}{c}\text { White } \\
\left(230^{\circ} \mathrm{C}\right)\end{array}$ & 1070 & $1100-1151$ \\
$\begin{array}{l}\text { Potassium } i s o \text {-propyl } \\
\text { xanthate }\left(\mathrm{C}_{4} \mathrm{H}_{7} \mathrm{OKS}_{2}\right)\end{array}$ & $\begin{array}{c}\text { White } \\
\left(274^{\circ} \mathrm{C}\right)\end{array}$ & 1075 & $1120-1165$ \\
$\begin{array}{l}\text { Potassium } n \text {-butyl } \\
\text { xanthate }\left(\mathrm{C}_{5} \mathrm{H}_{9} \mathrm{OKS}_{2}\right)\end{array}$ & $\begin{array}{c}\text { Light yellow } \\
\left(254^{\circ} \mathrm{C}\right)\end{array}$ & 1110 & $1150-1180$ \\
$\begin{array}{l}\text { Potassium } i s o-\text { butyl } \\
\text { xanthate }\left(\mathrm{C}_{5} \mathrm{H}_{9} \mathrm{OKS}_{2}\right)\end{array}$ & $\begin{array}{c}\text { Light yellow } \\
\left(262^{\circ} \mathrm{C}\right)\end{array}$ & 1015 & $1130-1125$ \\
\hline
\end{tabular}

Delhi and germination studies were conducted at room temperature $\left(28 \pm 2{ }^{\circ} \mathrm{C}\right)$. The seeds were surface sterilized with 0.1 $\%$ mercuric chloride solution for $2 \mathrm{~min}$, washed three times with water and germinated in petri dishes $(11 \mathrm{~cm})$ lined with filter paper and moistened with different test solution of 5,10 , 25 and 100 ppm potassium $n$-propyl xanthate, potassium isopropyl xanthates, potassium $n$-butyl xanthate, potassium isobutyl xanthates. Distilled water was used as control solution. Three replicate (each consisting of 20 seedlings) of each chemical treatment were maintained. Percent germination, length and dry weight of shoot and root were recorded 8 days after soaking in test solutions. For each observation, sample in triplicate (each consisting of 10 seedlings) were taken 
TABLE-2

GERMINATION AND SEEDLING GROWTH IN WHEAT IN VARIOUS XANTHATE VALUES ARE THE AVERAGE OF 30 SEEDLINGS

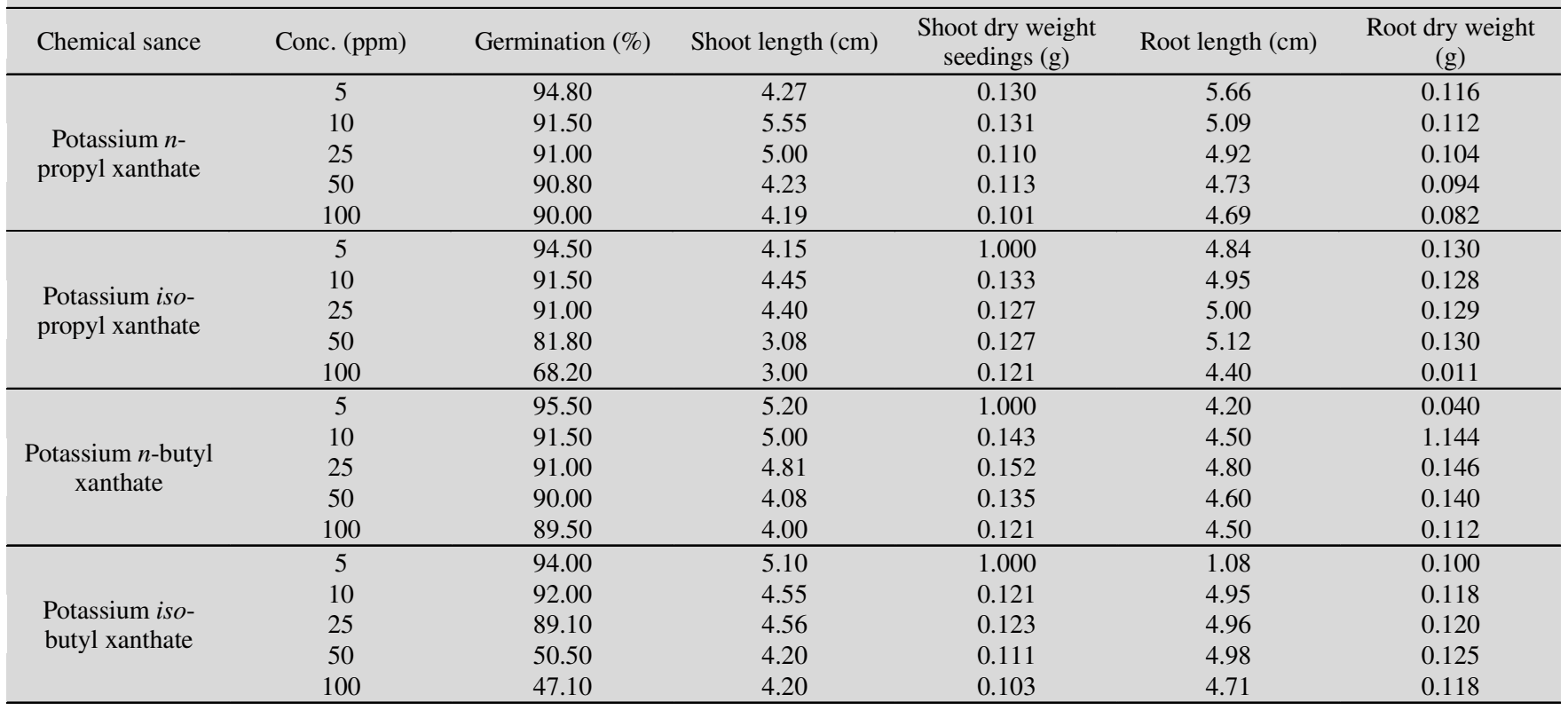

randomly. The data were subjected to statistical analysis based on analysis of variance according to Brunning and Kintz 2 .

Percent germination decreased as the concentration of chemical increased (Table-2). The behaviour of potassium $n$-propyl xanthate, potassium $n$-butyl xanthate and potassium iso-propyl xanthate were almost similar while potassium iosbutyl xanthate significantly decrease germination about by $50 \%$ at 50 and $100 \mathrm{ppm}$. This indicate that iso-butyl group significantly decreases percent germination as compared with other xanthate. Chemical treatments have differentially affected seedling growth at different concentrations. Length and dry weight of shoots had been increased at 5 and $10 \mathrm{ppm}$ potassium iso-propyl xanthate and either decreased or were not affected significantly by other chemical treatments (Table-2). Root length increased at 5, 10 and $25 \mathrm{ppm}$ potassium iso-propyl xanthates and potassium $n$-butyl xanthates, These findings indicate that a $n$-butyl group when attached with xanthate favours cell division and enlargement at shoot and root apices which ultimately increased dry matter production. Iso-propyl xanthate favours cell division and enhancement only at root apices at 5, 10 and $25 \mathrm{ppm}$, resulting in increased root length but not in increased root dry weight, thus indicating a differential effect on length and dry weight of root. Probably $n$ butyl xanthate group regulates the endogenous level of growth promoters such as auxin and gibberellins at lower concentrations and ultimately induce cell division and enlargement. The other group such as $n$-propyl xanthate, iso-butyl xanthate decreased length and dry weight of shoots and roots probably because of inhibition in mitotic activity by increasing endo- genous levels of growth inhibitors in developing seedlings. This view, however, need further experimental proofs on the activity of growth promoters and inhibitors in developing seedling of wheat (Triticum aestivum L.).

\section{REFERENCES}

1. J.D. Bebley and M. Black, Physiology and Biochemistry of Seeds in Relation to Germination, Springer-Verlag, Berlin, p. 306 (1978).

2. J.L. Brunni and B.L. Kintz, Compution Hand Book of Statistics, Scott Foreman and Co. England, p. 138 (1977).

3. A.A. Khan, The Physiology and Biochemistry of Seed Dormancy and Germination, North Holland Publishing Co, Newyork, p. 447 (1977).

4. S. Çelik and E. Yucel, Asian J. Chem., 20, 4051 (2010).

5. P. Kumar and B.D. Baijal, Indian J. Exp. Biol., 16, 269 (1977).

6. P. Kumar, B.D. Baijal and A.K. Agarwal, Proc. International Seminar on Approches Towarads Increasing the Potato Production in Developing Seminar on Approches Towards Increasing the Potato Production in Developing Countries, CRPS, Jullundhers, Abstract Code No. 500, PS IV 12, pp. 39-40 (1978)

7. P. Kumar, B.D. Baijal and R.A. Sharma, Acta Bot. Indica, 6, 167 (1978).

8. A. Lang, Ann. Rev. Plant Physiol., 21, 537 (1970).

9. T.C. Moore, Biochemistry and Physiology of Plant Hormones, Narosa Pub. Kouze, New Delhi, p. 274 (1980).

10. K.K. Nanda, Final Report of PL-480 Research Project A-7-FS-11 (FG in 225), August (1970).

11. A. Horii, P. McCue and K. Shetty, Bioresour. Technol., 98, 623 (2007).

12. H. Safari, A. Tavili and M. Saberi, Front. Agric. China, 4, 475 (2010).

13. M. Saberi, Shahriari Alireza and T Faro, Front. Agric. China, 5, 301 (2011).

14. J. Mohammad and S. Hamie, Front. Agric. China, 5, 310 (2011). 